\title{
Transition from Cellulose I Family to Cellulose II Family
}

\author{
Masae TAKAHASHI and Haruko TAKENAKA \\ Faculty of Home Economics, Japan Women's University, \\ 2-8-1 Mejirodai, Bunkyo-ku, Tokyo 112, Japan
}

(Received November 1, 1986)

\begin{abstract}
To make clear the mechanism of the transition from Cell (cellulose) I to Cell II, the changes of the crystal structure and the chain conformation during the mercerization reaction process are studied under various conditions by means of wide angle X-ray diffractograms and $\mathrm{CP} / \mathrm{MAS}{ }^{13} \mathrm{C}$ NMR spectra. It was observed that Cell I and Cell II show the different ${ }^{13} \mathrm{C}$ NMR spectra resulting from the different chain conformations. In Na-cells treated with three conditions of fixing the fibers, $\mathrm{CP} / \mathrm{MAS}{ }^{13} \mathrm{C}$ NMR spectra show different patterns which result from two types of the chain conformations, that is Na-cell of Cell I type and that of Cell II type. By regeneration, the Na-cell of Cell II type conformation transforms to Cell II regardless of the temperature of washing water. On the other hand, the Na-cell of Cell I type conformation mostly transforms to Cell I by washing with water at higher temperature. From these results, it seems reasonable to conclude that the transition from Cell I to Cell II is caused by the change of the chain conformation, as proposed by Hayashi.
\end{abstract}

KEY WORDS Cellulose / Transition / CP/MAS ${ }^{13}$ C NMR / Mercerization / Chain Conformation / Chain Packing /

It is recognized that cellulose I (Cell I) family can be transformed into cellulose II (Cell II), but that the reverse is impossible. Such an irreversible phenomenon has been explained by mainly two different proposals. ${ }^{1-5}$ One is the proposal by Hayashi et al., ${ }^{1,2}$ which claims that the types of chain conformation in Cell I family and in Cell II family are different and the conformation of Cell II type is more stable than that of Cell I type. The other proposal by Sarko and Blackwell et al..$^{3-5}$ is that Cell I and Cell II have parallel and antiparallel chain packings, respectively, and that antiparallel chain packing is the lowest energy form. However, it seems unclear which proposal is more plausible.

Cell II does not exist naturally, but can be obtained from the native material by mercerization which involves swelling treatment with sodium hydroxide. Therefore, the study of the mercerization process is important to make clear the mechanism of the transition from Cell I to Cell II. In this paper, the changes of crystal structure and the chain conformation during the mercerization are investigated under various conditions by means of wide angle $\mathrm{X}$-ray diffractograms and ${ }^{13} \mathrm{C}$ NMR solidstate spectra, and the transition mechanism is discussed.

\section{EXPERIMENTAL}

The starting material of Cell I was ramie, of which crystallinity measured by X-ray method was about $90 \%$. The sodium cellulose I (NaCell I) was prepared from ramie by treatment with $15 \%$ aqueous $\mathrm{NaOH}$ solution ${ }^{6}$ at $20^{\circ} \mathrm{C}$ for 1 hour, 1 day, and 1 week under the following three conditions of fixing fibers: the fibers were wound tightly around a glass plate to keep fixed length (A), the fibers were wound loosely around a glass plate to allow shrinkage by about $30 \%$ (B) and the fibers were allowed 
to shrink freely (C). After air-dry treatment for 24 hours at about $20^{\circ} \mathrm{C}$ under these conditions, the sodium celluloses were removed from a glass plate.

In the case of X-ray diffraction measurements, Cell I, Cell II, sodium celluloses (Nacells) and regenerated celluloses in the dry state were wound around stainless steel plates to make their fiber axis parallel to the specimen holder surface. The equatorial diffractograms of these specimen were examined with an X-ray diffractometer. The X-ray source was the nickel-filtered $\mathrm{Cu}-K_{\alpha}$ radiation from a generator operating at $30 \mathrm{kV}$ and $15 \mathrm{~mA}$. A divergence slit of $1^{\circ}$ was used and a slit of $0.15 \mathrm{~mm}$ for receiving diffracted rays. The contents of Cell I and Cell II in the regenerated celluloses were calculated by the method of Rånby. ${ }^{7}$

To obtain quantitative informations on the chain conformation, ${ }^{8}$ cross polarization/magic angle spinning (CP/MAS) ${ }^{13} \mathrm{C}$ NMR spectra were recorded on JEOL JNM FX-200 and GX-270 spectrometers equipped with a

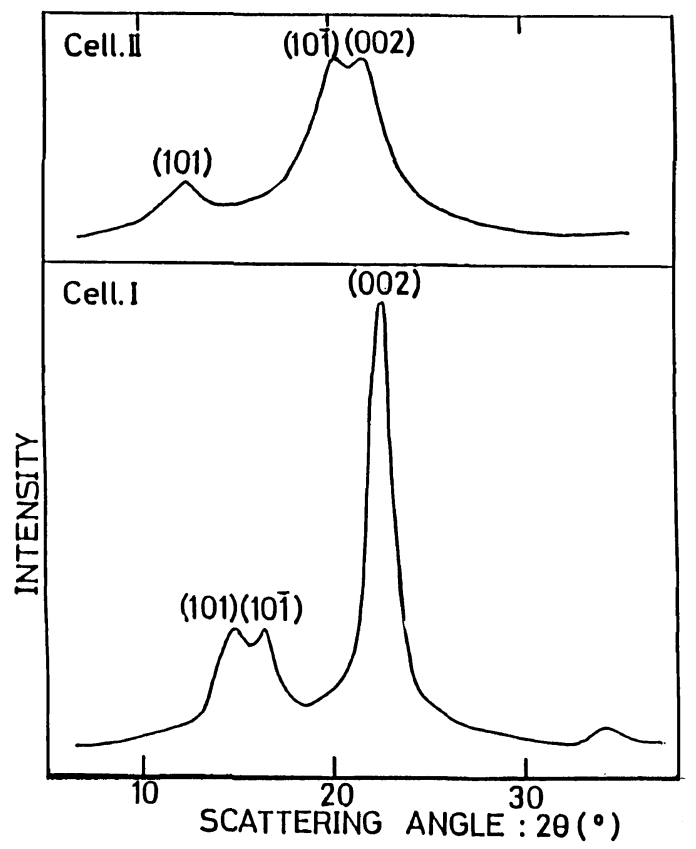

Figure 1. Equatorial $X$-ray diffractograms of ramie (Cell I) and viscous rayon (Cell II).
$\mathrm{CP} / \mathrm{MAS}$ unit operating at 50.2 and $67.8 \mathrm{MHz}$ for ${ }^{13} \mathrm{C}$, respectively. Chemical shifts $\delta$ relative to tetramethylsilane were determined using a narrow crystalline resonance line at $29.5 \mathrm{ppm}$ for adamantan. The specimens wound into ball, were packed closely in a rotor.

\section{RESULTS AND DISCUSSION}

Figure 1 shows the typical equatorial X-ray diffractograms of Cell I and Cell II. Figure 2 shows the X-ray diffractograms of $\mathrm{Na}$-Cell prepared under (A), (B), and (C) conditions. These diffractograms are different from Cell I and Cell II shown in Figure 1, and are divided into (A), (B), and (C) groups depending on the condition of the fixing fibers.

Figure 3 shows X-ray diffractograms of

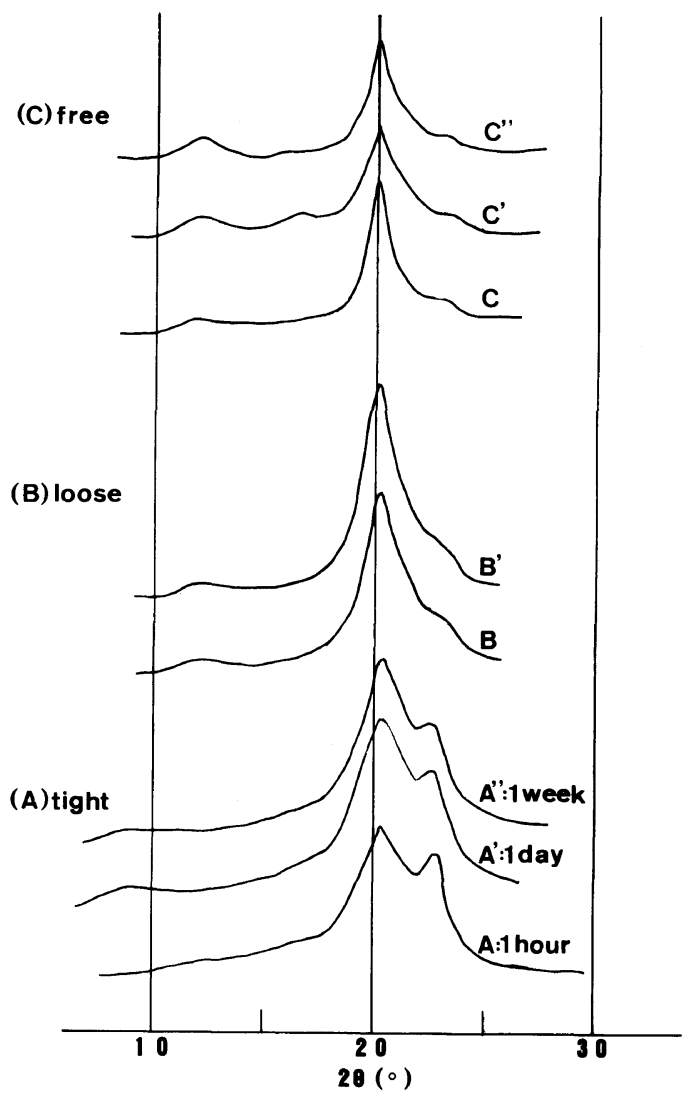

Figure 2. Equatorial X-ray diffractograms of Na-cells prepared under (A), (B), and (C) conditions. 
Transition from Cell I to Cell II Family

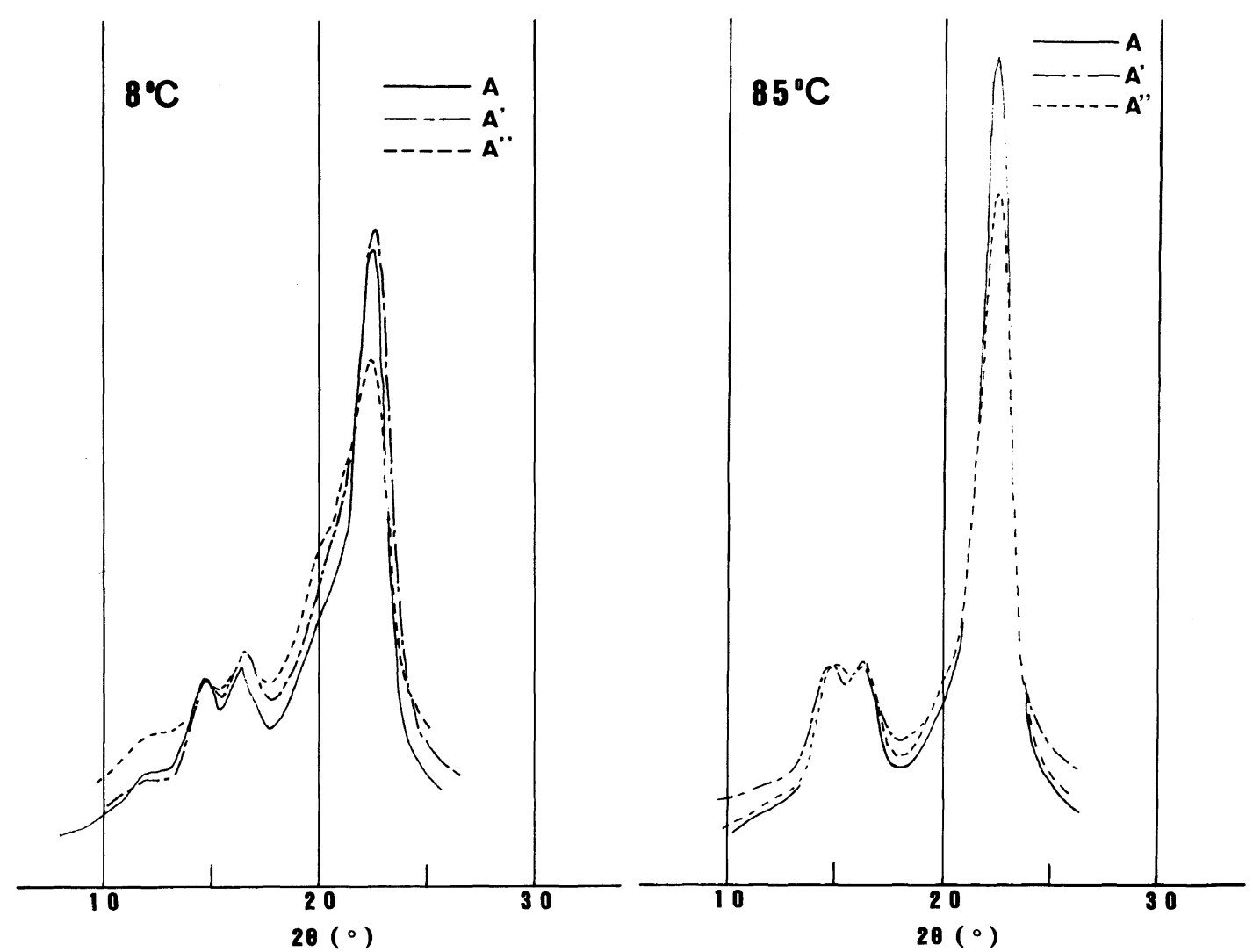

Figure 3. X-Ray diffractograms of cellulose regenerated from (A) group (A, $A^{\prime}$, and $\left.A^{\prime \prime}\right)$ with water at $8^{\circ} \mathrm{C}$ and $85^{\circ} \mathrm{C}$.

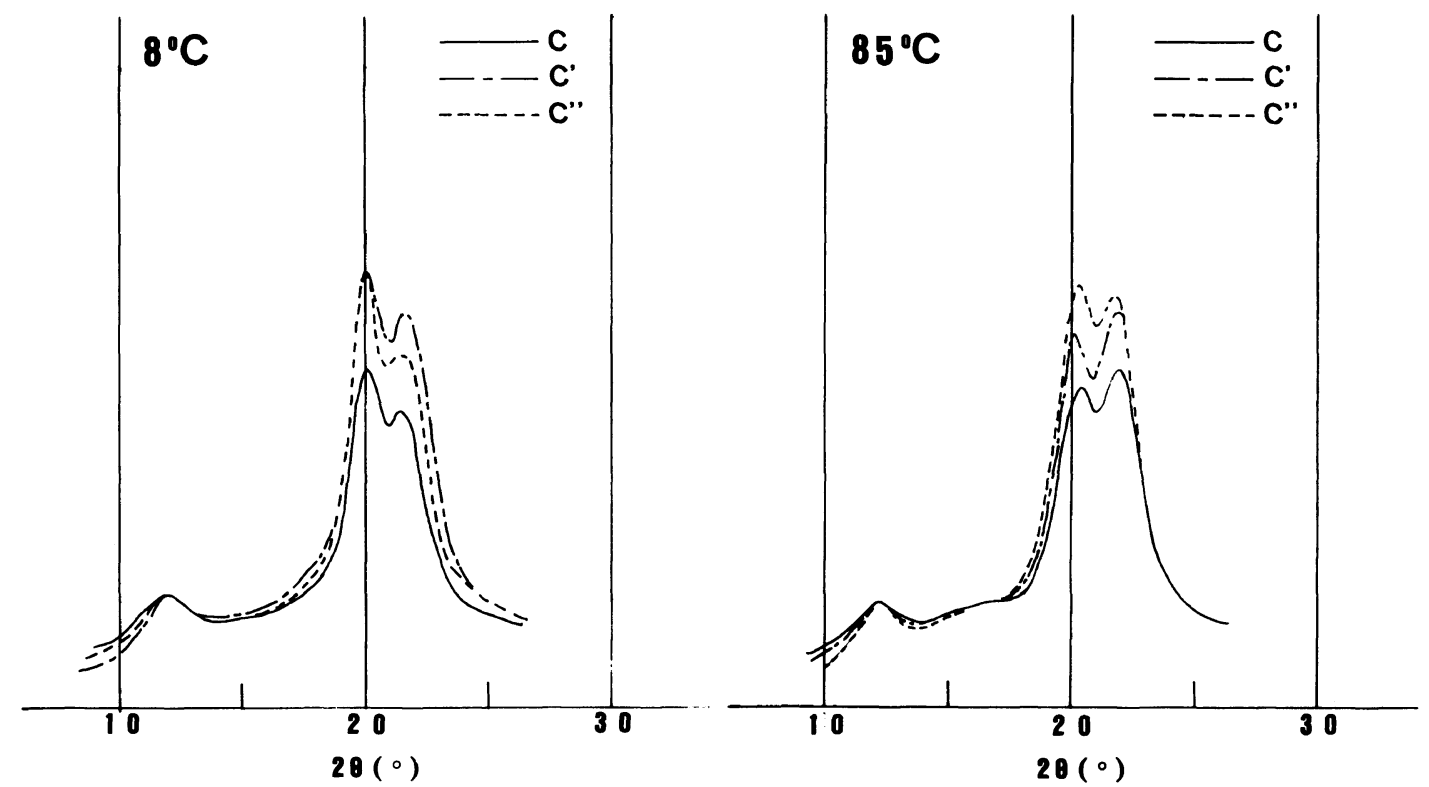

Figure 4. X-Ray diffractograms of cellulose regenerated trom $(C)$ group $\left(C, C^{\prime}\right.$, and $\left.C^{\prime \prime}\right)$ with water at $8^{\circ} \mathrm{C}$ and $85^{\circ} \mathrm{C}$. 

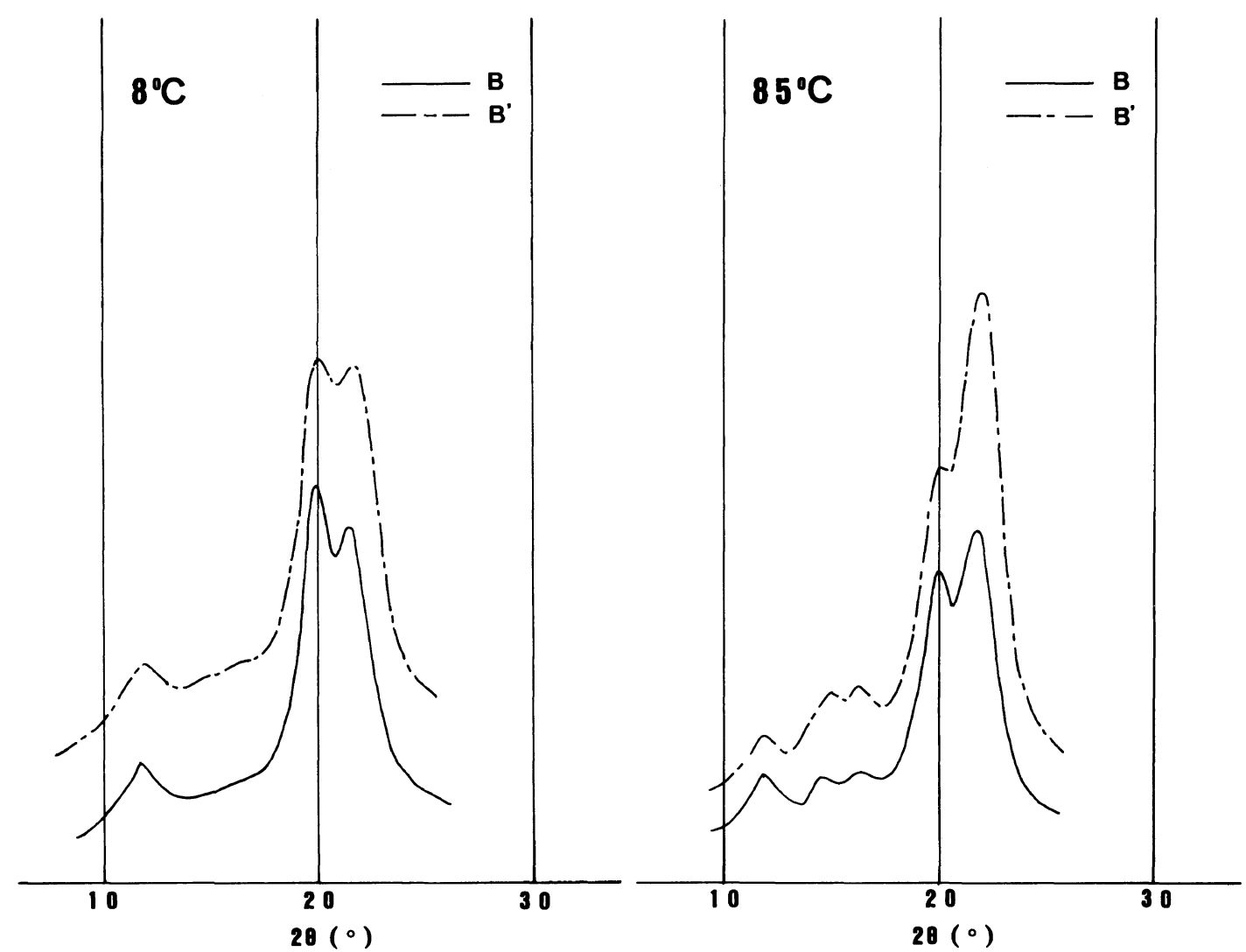

Figure 5. X-Ray diffractograms of cellulose regenerated from (B) group (B and $\mathrm{B}^{\prime}$ ) with water at $8^{\circ} \mathrm{C}$ and $85^{\circ} \mathrm{C}$.

cellulose which was regenerated from (A) group $\left(\mathrm{A}, \mathrm{A}^{\prime}\right.$, and $\left.\mathrm{A}^{\prime \prime}\right)$ of the $\mathrm{Na}$-cell with water at 8 and $85^{\circ} \mathrm{C}$ for $15 \mathrm{~min}$ and was dried for 24 hours at about $20^{\circ} \mathrm{C}$ under a condition of not fixing fibers. In this case, each cellulose which was regenerated with water at $85^{\circ} \mathrm{C}$ returns to Cell $\mathrm{I}$. On the other hand, with water at $8^{\circ} \mathrm{C}$, the content of Cell II in the regenerated celluloses increases with the time of mercerization. It is considered that Cell II in the regenerated celluloses from (A) group was prepared from the crystalline modification of the Cell I type under harder swelling conditions by cold water. The results agree with those for $\mathrm{Na}$-cell by Hayashi. ${ }^{9}$

The results obtained from $(\mathrm{C})$ group $\left(\mathrm{C}, \mathrm{C}^{\prime}\right.$, and $\left.\mathrm{C}^{\prime \prime}\right)$ in a similar way are shown in Figure 4. Each regenerated cellulose is completely transformed into Cell II regardless of the temperature of washing water. So, it is suggested that the change of the chain conformation or the chain packing from the Cell I type to the Cell II type may result in the ramie mercerized with $15 \% \mathrm{NaOH}$ for only 1 hour in (C) condition.

Figure 5 shows the results obtained from (B) group (B and $\left.\mathrm{B}^{\prime}\right)$ in a similar way, of which $\mathrm{X}$ ray diffractograms are almost similar to those of (C) group. The content of Cell II is about $100 \%$ at $8{ }^{\circ} \mathrm{C}$ and about $30-60 \%$ at $85^{\circ} \mathrm{C}$ for $\mathrm{B}$ and $\mathrm{B}^{\prime}$. These results suggest that the chain conformation or the chain packing has changed from the mixture of the Cell I and Cell II types to the Cell II type in Na-cell prepared from (B) group. ${ }^{10}$

In order to know more clearly the chain 
Transition from Cell I to Cell II Family

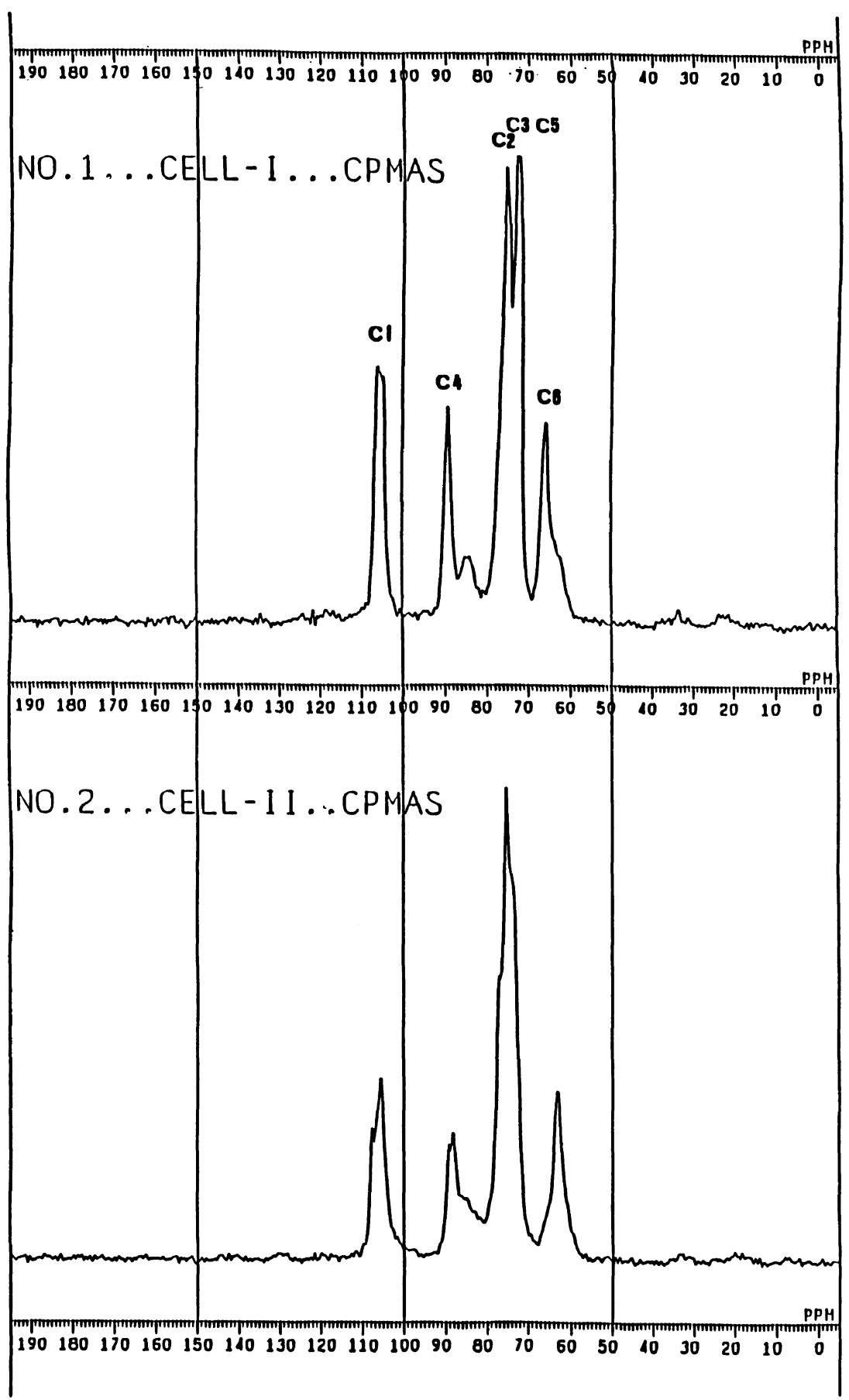

Figure 6. $67.8 \mathrm{MHz} \mathrm{CP} / \mathrm{MAS}{ }^{13} \mathrm{C}$ NMR spectra of ramie in Cell I and mercerized ramie in Cell II. 
Table I. ${ }^{13} \mathrm{C}$ chemical shifts of ramie in Cell I and mercerized ramie in Cell II in the solid state

\begin{tabular}{ccccc}
\hline & \multicolumn{4}{c}{$\delta / \mathrm{ppm}$} \\
\cline { 2 - 5 } & $\mathrm{C}_{1}$ & $\mathrm{C}_{4}$ & $\mathrm{C}_{6}$ & $\mathrm{C}_{2} \mathrm{C}_{3} \mathrm{C}_{5}$ \\
\hline Cell I & $105.9,104.7$ & 89.1 & 65.6 & $75.3,72.7,72.0$ \\
Cell II & $107.5,105.5$ & $89.0,88.1$ & 63.1 & $76.9,75.2,73.7$ \\
\hline
\end{tabular}

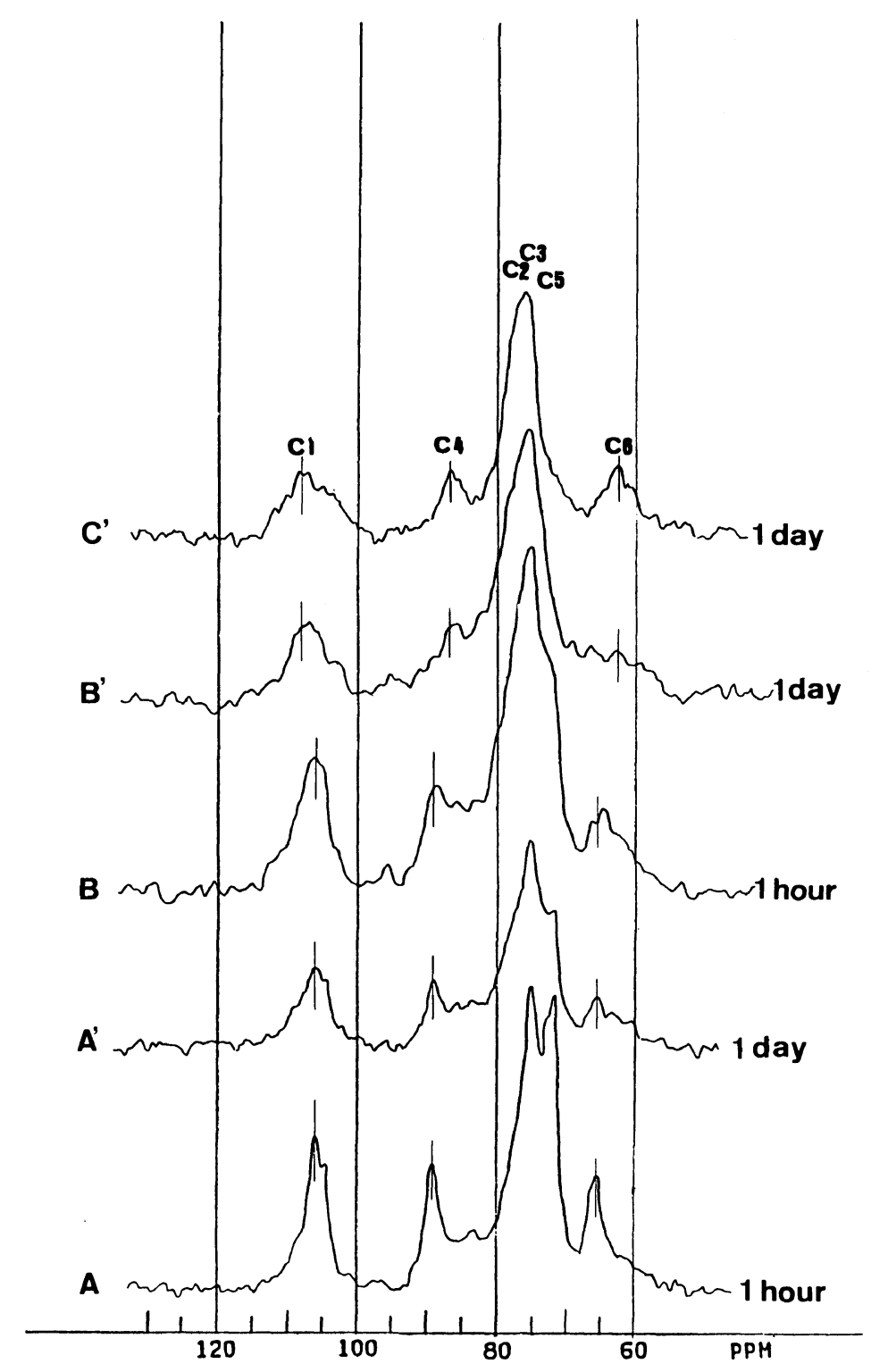

Figure 7. $50.2 \mathrm{MHz} \mathrm{CP} / \mathrm{MAS}{ }^{13} \mathrm{C}$ NMR spectra of various $\mathrm{Na}$-cell samples $\left(\mathrm{A}, \mathrm{A}^{\prime}, \mathrm{B}, \mathrm{B}^{\prime}\right.$, and $\left.\mathrm{C}^{\prime}\right)$. 
conformation of various $\mathrm{Na}$-cells $\left(\mathrm{A}, \mathrm{A}^{\prime}, \mathrm{B}\right.$, $B^{\prime}$, and $C^{\prime}$ ), CP/MAS ${ }^{13} \mathrm{C}$ NMR spectra were investigated. Figure 6 shows the $\mathrm{CP} / \mathrm{MAS}{ }^{13} \mathrm{C}$ NMR spectra of ramie in Cell I and mercerized ramie in Cell II. The signals in the spectral regions of $60-68,70-78,86-91$, and $103-$ $109 \mathrm{ppm}$ belong to those of $\mathrm{C}_{6}, \mathrm{C}_{2}-\mathrm{C}_{3}-\mathrm{C}_{5}, \mathrm{C}_{4}$, and $C_{1}$ carbons, respectively. ${ }^{8}$ The chemical shifts of their respective carbons are shown in Table $\mathrm{I}$. It is evident that the $\mathrm{C}_{1}$ resonance line, and $\mathrm{C}_{4}$ and $\mathrm{C}_{6}$ resonance lines in Cell II result in down and up fields, respectively, as compared with those in Cell I. For comparison, $\mathrm{C}_{1}$, $\mathrm{C}_{4}$, and $\mathrm{C}_{6}$ resonance lines of each Na-cell are shown in Figure 7. The vertical lines marked in the spectrum of specimens $A, A^{\prime}$, and $B$ indicate the position of the $\mathrm{C}_{1}, \mathrm{C}_{4}$, and $\mathrm{C}_{6}$ lines of Cell I shown in Table $\mathrm{I}$ and the lines in specimens $B^{\prime}$ and $C^{\prime}$ indicate those of Cell II. The positions of respective peaks in $A$ and $A^{\prime}$ coincide with Cell $\mathrm{I}$ lines, so $\mathrm{A}$ and $\mathrm{A}^{\prime}$ are considered to have the Na-cell of the Cell I type conformation. Similarly, $\mathrm{C}^{\prime}$ is considered to have the $\mathrm{Na}$-cell of Cell II type conformation. On the other hand, for $\mathrm{B}^{\text {and }} \mathrm{B}^{\prime}$, it is concluded that these specimens are not composed of complete $\mathrm{Na}$-cells of Cell II type conformation but mixtures of the Na-cell of Cell I type and that of Cell II type conformations.

Since the families of Cell I type and Cell II type in Na-cells have different chain conformations, it may be reasonable to conclude that the transition from Cell I to Cell II is caused by the change of the chain conformation, as proposed by Hayashi.

\section{CONCLUSION}

In mercerization of ramie under various conditions of fixing fibers, the contents of Cell I and Cell II are estimated from X-ray diffractograms, and the chain conformation is studied by analysis of ${ }^{13} \mathrm{C}$ NMR spectra, to make clear the transition mechanism from Cell I to Cell II.

It is observed that Cell I and Cell II show different ${ }^{13} \mathrm{C}$ NMR spectra resulting from different chain conformations. In $\mathrm{Na}$-cells treated under three conditions of fixing fibers, $\mathrm{CP} / \mathrm{MAS}{ }^{13} \mathrm{C}$ NMR spectra show different patterns resulting from two types of the chain conformations, that is, the Na-cell of Cell I type and that of Cell II type conformations. By regeneration, the $\mathrm{Na}$-cell of Cell II type conformation transforms to Cell II regardless of the temperature of washing water. On the other hand, the Na-cell of Cell I type conformation mostly transforms to Cell I by washing with water at higher temperature.

From these results, it may be reasonable to conclude that the transition from Cell I to Cell II is caused by the change of the chain conformation, as proposed by Hayashi.

Acknowledgment. The authors wish to express their appreciation to Dr. P. H. Kim for his valuable comments and guidance.

\section{REFERENCES}

1. J. Hayashi, A. Sueoka, and S. Watanabe, Nippon Kagaku Kaishi, 153 (1973).

2. H. Hatakeyama, Sen'i Gakkai Shi, 39, 388 (1983).

3. A. J. Stipanovic and A. Sarko, Macromolecules, 9 , 851 (1976).

4. F. J. Kolpak and J. Blackwell, Macromolecules, 9, 273 (1976).

5. T. Okano, Abstracts of Papers, the 100th Kami-Pulp Meeting of Sen'i Gakkai, 1984, p 1.

6. H. Sobue, H. Kiessing, and K. Hess, Z. Phys. Chem., B43, 309 (1939).

7. B. G. Rånby, Acta Chem. Scand., 6, 116 (1952).

8. F. Horii, A. Hirai, and R. Kitamaru, Polym. Bull., 8, 163 (1982).

9. J. Hayashi, T. Yamada, and K. Kimura, Appl. Polym. Symp., No. 28, 713 (1976).

10. M. Takahashi and H. Takenaka, Sen'i Gakkai Shi, 36, T-223 (1980). 